\title{
Climate change affects key nitrogen-fixing bacterial populations on coral reefs
}

\author{
Henrique F Santos ${ }^{1,2}$, Flávia L Carmo ${ }^{1}$, Gustavo Duarte ${ }^{3}$, Francisco Dini-Andreote ${ }^{2}$, \\ Clovis B Castro ${ }^{3,4}$, Alexandre S Rosado ${ }^{1,4}$, Jan Dirk van Elsas ${ }^{2}$ and Raquel S Peixoto ${ }^{1,4}$ \\ ${ }^{1}$ LEMM, Laboratory of Molecular Microbial Ecology, Institute of Microbiology Paulo de Góes, Federal \\ University of Rio de Janeiro (UFRJ), Rio de Janeiro, Brazil; ${ }^{2}$ Department of Microbial Ecology, Centre \\ for Ecological and Evolutionary Studies, University of Groningen, Groningen, The Netherlands; \\ ${ }^{3}$ National Museum, UFRJ, Rio de Janeiro, Brazil and ${ }^{4}$ Coral Vivo Institute, Rio de Janeiro, Brazil
}

\begin{abstract}
Coral reefs are at serious risk due to events associated with global climate change. Elevated ocean temperatures have unpredictable consequences for the ocean's biogeochemical cycles. The nitrogen cycle is driven by complex microbial transformations, including nitrogen fixation. This study investigated the effects of increased seawater temperature on bacteria able to fix nitrogen (diazotrophs) that live in association with the mussid coral Mussismilia harttii. Consistent increases in diazotroph abundances and diversities were found at increased temperatures. Moreover, gradual shifts in the dominance of particular diazotroph populations occurred as temperature increased, indicating a potential future scenario of climate change. The temperature-sensitive diazotrophs may provide useful bioindicators of the effects of thermal stress on coral reef health, allowing the impact of thermal anomalies to be monitored. In addition, our findings support the development of research on different strategies to improve the fitness of corals during events of thermal stress, such as augmentation with specific diazotrophs.
\end{abstract}

The ISME Journal (2014) 8, 2272-2279; doi:10.1038/ismej.2014.70; published online 16 May 2014

Subject Category: Microbial ecosystem impacts

Keywords: climate change; coral reef; nitrogen cycle; Mussismilia harttii; diazotrophs

\section{Introduction}

Coral reefs constitute ecosystems that harbor a myriad of interwoven species. These ecosystems have key roles in the maintenance of marine biodiversity. Although coral reefs account for only $0.1 \%$ of the total ocean area, they host $25 \%$ of all marine macro-organisms that live in the oceans (Burke et al., 2011). Furthermore, they have an important role in the biogeochemical cycles of carbon, nitrogen and phosphorus that occur in the sea (Wild et al., 2005). Coral reefs are being threatened by direct anthropogenic impacts as well as by the effects of global climate change, which may result in a reduction in the $\mathrm{pH}$ of seawater and rising water temperatures (Hoegh-Guldberg et al., 2007; Hoegh-Guldberg and Bruno, 2010; Burke et al.,

Correspondence: JD van Elsas, Department of Microbial Ecology, Centre for Ecological and Evolutionary Studies, University of Groningen, Groningen, The Netherlands.

E-mail: j.d.van.elsas@rug.nl

or RS Peixoto, General Microbiology, Federal University of Rio de Janeiro, Av Carlos Chagas Filho, 373, CCS, Bloco E, Rio de Janeiro 21 944970, Brazil.

E-mail: raquelpeixoto@micro.ufrj.br

Received 20 November 2013; revised 17 March 2014; accepted 23 March 2014; published online 16 May 2014
2011). Such stresses have already been linked to disease outbreaks in coral reef ecosystems (Sutherland et al., 2004; Selig et al., 2006).

Corals live in symbiotic relationships with a plethora of organisms, including endosymbiotic dinoflagellate algae (zooxanthellae), bacteria, archaea and fungi (Falkowski et al., 1984; Rohwer et al., 2002; Knowlton and Rohwer, 2003; Reshef et al., 2006). The whole association has been described as a holobiont (Rosenberg et al., 2007). Intricate relationships may exist between members of the microbial community that occur in the coral holobiont. An example is the production of dimethylsulfoniopropionate by symbiotic zooxanthellae (Keller et al., 1989), which has been implicated in the prevention of deleterious bacterial colonization of coral. The presence of dimethylsulfoniopropionate and related sulfur compounds may provide a selective environment in which the survival of microbes is restricted (Barott and Rohwer, 2012). Dimethylsulfoniopropionate is a precursor of the volatile organic sulfur compound dimethyl sulfide, which may have a role in the formation of clouds and thus acts as a climatecooling gas (Charlson et al., 1987). On the other hand, the growth and abundance of zooxanthellae is limited by the availability of nitrogen (Falkowski 
et al., 1993). In nitrogen-limited coral systems, the abundance of zooxanthellae may depend on the activity of diazotrophic bacteria (Lesser et al., 2007; Olson et al., 2009; Lema et al., 2012).

Recent studies have shown that increases in seawater temperature can cause shifts in the coralassociated microbial communities (for example, Bourne et al., 2008). However, the effects of temperature increase on the diazotrophic bacterial populations of corals, and the effect of this on coral health, remains unclear. The current study aimed to foster our understanding of the effect of increases in seawater temperature on the abundance and diversity of diazotrophic microbial populations associated with the coral Mussismilia harttii. In the present study, a comparison was made between mesocosms held at elevated temperatures and mesocosms maintained at ambient temperatures. Analysis of nifH genes, which encode the key dinitrogen reductase enzyme, was used to evaluate the abundance, community structure, species richness and diversity of the diazotrophic communities in individual coral specimens from mesocosms maintained at different temperatures. An enhanced understanding of coral-associated nitrogen-fixing bacterial communities on coral reefs contributes to our understanding of the resilience of coral reefs and the possible changes in the marine nitrogen cycle in the face of climate change. In addition, it aids in the establishment of potential management guidelines for future environmental protection programs.

\section{Materials and methods}

Sample collection and experimental design

M. harttii specimens were collected in 'Recife de Fora', a reef located $\sim 3.2 \mathrm{~km}$ offshore near the city of Porto Seguro, Bahia, Brazil (between latitude $16^{\circ} 23^{\prime} 30^{\prime \prime} \mathrm{S}$ and $16^{\circ} 25^{\prime} 06^{\prime \prime} \mathrm{S}$ and longitude $38^{\circ} 58^{\prime} 30^{\prime \prime} \mathrm{W}$ and $38^{\circ} 59^{\prime} 18^{\prime \prime} \mathrm{W}$ ). The reef area is $\sim 17.5 \mathrm{~km}^{2}$, and the water depth surrounding the reef is $\sim 20 \mathrm{~m}$. Seawater was sampled at ambient temperature $\left(\sim 27^{\circ} \mathrm{C}\right)$. Annual temperature fluctuation ranged between $24.06{ }^{\circ} \mathrm{C}(\mathrm{min})$ and $29.00{ }^{\circ} \mathrm{C}$ (max), and the average water temperature was $26.74{ }^{\circ} \mathrm{C}$ ( \pm 1.01$)$. The $M$. harttii colonies had polyps, which showed loose tissue connection with adjacent polyps. Therefore, single- or double-polyp structures were used as sampling units without harming their tissues. Physiological experiments were conducted in mesocosms established at an onshore research station, near the reef area where the samples had been collected.

Sixteen mesocosm tanks (130l each) were supplied with seawater that was captured continuously from a fringe reef near the research station. The seawater supply rate was $8.6 \mathrm{lmin}^{-1}$ for each tank, providing a fourfold replacement of the mesocosm volume every hour to mimic the daily and seasonal variations that were naturally observed in the reef. The mesocosm tanks received only natural sunlight and therefore followed natural day/night cycles. To mimic the amount of incident light in the reefs, the tanks were covered with a $70 \%$ shade screen, resulting in $350 \mu \mathrm{mol}$ photons $\mathrm{m}^{-2} \mathrm{~s}^{-1}$ at noon, which is consistent with the average parameters measured in situ at $2.5 \mathrm{~m}$ depth in the 'Recife de Fora' reef.

Five different polyps from four different coral outcrops all belonging to the same species, $M$. harttii ( $=M$. harttii 20 polyps), were collected in the reef area of 'Recife de Fora', Brazil. A total of five treatments were evaluated (that is, pretreatment, control, $+1.0,+2.0$ and $\left.+4.5^{\circ} \mathrm{C}\right)$. One polyp from each coral outcrop was used in each of the different treatments, thus generating four replicates per treatment. The pretreatment samples were frozen at $-20{ }^{\circ} \mathrm{C}$ immediately after sampling. Polyps subjected to the other treatments were transferred to the experimental tanks $(<12 \mathrm{~h})$. Polyps in tanks were kept at natural seawater temperature for acclimation for 15 days. After this period, the tanks were subjected to the temperature treatments for a period of 21 days, as follows: ambient water temperature (tank control) and three different elevated water temperatures $(+1.0,+2.0$ and $+4.5^{\circ} \mathrm{C}$ ) above the ambient temperature. One polyp from each of the four coral outcrops was used in each of the five different treatments, thus generating four replicates per treatment.

For quantitative PCR (qPCR), denaturing gradient gel electrophoresis (DGGE) analyses, and evaluation for maximum quantum yield of the Photosystem II $(\mathrm{Fv} / \mathrm{Fm})$, all treatments were sampled. For clone library analyses, samples from the following treatments were analyzed: pretreatment, control, +2.0 and $+4.5^{\circ} \mathrm{C}$.

Photosystem II photochemical efficiency: pulse amplitude modulation fluorometry

Samples were evaluated for maximum quantum yield of the Photosystem II (Fv/Fm) using a submersible pulse-amplitude-modulated chlorophyll fluorometer (Diving-PAM, Walz, Effeltrich, Germany) as a proxy for the 'health' of the coral holobiont (Schreiber, 2004). The measurements were taken after sunset in order to avoid interference by diurnal photo-inhibition artifacts, after full recovery of the reaction centers. The results were analyzed using a nested analysis of variance with Statistica 7 software (StatSoft, Tulsa, OK, USA), considering the data from four replicate tanks per treatment and three polyps from three different areas of the reef per tank.

\section{Community DNA extraction}

To assess the diazotroph communities in M. harttii, $0.5 \mathrm{~g}$ of dried material from each coral sample was macerated using a mortar and pestle. Total community DNA extraction was performed using the ZR Soil Microbe DNA Kit (Zymo Research, Irvine, CA, USA) (Santos et al., 2012). The DNA quality and 
concentration was evaluated using a Qubit fluorometer (Invitrogen, Carlsbad, CA, USA). The amount, average molecular weight and quality of the DNA were further assessed using conventional electrophoresis in $0.8 \%$ agarose gels with $0.56 \mathrm{x}$ TBE buffer (45 mm Tris-Borate, 1 mm EDTA, pH 8.0).

Measurement of nifH and 165 ribosomal RNA (rRNA) gene abundances by $q P C R$

The abundance of the nifH genes (used as a proxy for the abundance of nitrogen fixers) and 16S rRNA genes (for total bacteria) was measured by qPCR. The reactions were performed in an ABI Prism 7300 Cycler (Applied Biosystems, Darmstadt, Germany) in $25 \mu \mathrm{l}$ reactions containing $1 \mu \mathrm{l}$ of DNA template (ca. $20 \mathrm{ng}$ ). For the nifH gene, Power SYBR green master mix was used $(12.5 \mu \mathrm{l})$ (Applied Biosystems), and $0.25 \mu \mathrm{M}$ each of primer FGPH19 (Simonet et al., 1991) and primer PolR (Poly et al., 2001). The amplification reactions were performed with an initial denaturation step at $95^{\circ} \mathrm{C}$ for $15 \mathrm{~min}$, followed by 30 cycles of $94^{\circ} \mathrm{C}(1 \mathrm{~min}), 55^{\circ} \mathrm{C}(27 \mathrm{~s})$ and $72^{\circ} \mathrm{C}(1 \mathrm{~min})$. For $16 \mathrm{~S}$ rRNA gene, Power SYBR green master mix was used $(12.5 \mu \mathrm{l})$ (Applied Biosystems), supplemented with $0.5 \mu \mathrm{l} 20 \mathrm{mg} \mathrm{ml}^{-1}$ of BSA and $0.25 \mu \mathrm{M}$ of each primer (FP16S/RP16S) (Bach et al., 2002). The cycling protocol was $95^{\circ} \mathrm{C}$ for $10 \mathrm{~min}$, followed by 40 cycles of $95^{\circ} \mathrm{C}(27 \mathrm{~s})$, $62{ }^{\circ} \mathrm{C}(1 \mathrm{~min})$ and $72{ }^{\circ} \mathrm{C}(30 \mathrm{~s})$. The specificity of the amplifications was confirmed by melting curve analysis. Possible inhibitory effects of co-extracted compounds were assessed by spiking samples with a range of known concentrations of the plasmid. No inhibition was observed in any of the samples. Standard curves covering 6 orders of magnitude, that is, from $10^{2}$ to $10^{7}$ copies of template per assay, were generated using plasmids containing cloned nifH from Bradyrhizobium liaoningense and a partial 16S rRNA gene from Serratia plymuthica. The qPCR efficiency $(E)$ was calculated according to the equation $E=\left[10^{(-1 / \text { slope })}-1\right]$.

\section{Analysis of the structure of diazotrophic communities} by PCR-DGGE

The total DNA extracted from all coral samples was subjected to amplification using nifH-specific primers, as described in the literature (Simonet et al., 1991; Poly et al., 2001) for DGGE analysis of nifH genes (Pereira e Silva et al., 2011). The amplicons obtained were checked on agarose gels before DGGE analysis. DGGE was performed in an Ingeny PhorU2 system (Ingeny, Goes, The Netherlands) using a $40-65 \%$ denaturing gradient (where $100 \%$ denaturant consisted of $7 \mathrm{M}$ urea and $40 \%$ formamide) and $6.0 \%$ polyacrylamide. Electrophoresis was carried out at $60^{\circ} \mathrm{C}$ at $100 \mathrm{~V}$ for $16 \mathrm{~h}$. After electrophoresis, gels were stained with SYBR Gold at a final concentration of $0.5 \mathrm{mgl}^{-1}$ (Invitrogen, Breda, The Netherlands) and photographed on a UV transilluminator. Images of the gels were obtained with Image Master VDS (Amersham Biosciences, Buckinghamshire, UK) and stored as TIFF files. DGGE patterns were compared by clustering the different lanes by Pearson's correlation implemented in GelCompar II software (Applied Maths, SintMartens-Latem, Belgium) using the unweighted-pair group method with arithmetic means.

Construction and analysis of nifH gene clone libraries The DNA extracted from each sample was used to construct nifH gene clone libraries. One clone library was constructed for each subregion of sampling points, given the high similarity of replicates in DGGE analysis. The template DNA was subjected to amplification with the nifH gene primers FGPH19 (Simonet et al., 1991) and PolR (Poly et al., 2001), according to previously described methodology (Taketani et al., 2009). The amplicons were purified using the Wizard SV gel and PCR clean-up system (Promega, Madison, WI, USA) and cloned in plasmid pGEM-T using the pGEM-T Easy Vector system kit (Promega) according to the manufacturer's instructions. Colonies that exhibited vector inserts (white) were selected for insert detection by amplification with the M13F and M13R primers. The resulting PCR products with the inserts were sequenced at AGOWA (Berlin, Germany). Prior to sequence analyses, all chromatograms were trimmed for quality and vector removal using the Lucy algorithm (Chou and Holmes, 2001) using a threshold base quality score $>20$ and sequence length $>100 \mathrm{bp}$. The obtained filtered sequences were aligned and inspected using MEGA 4.0 (Tempe, AZ, USA) (Tamura et al., 2007). Operational taxonomic unit (OTU)-based analyses were carried out using QIIME (Boulder, CO, USA) (Caporaso et al., 2010) by adding artificial barcodes/ primer at $5^{\prime}$ pre-trimmed sequences. The samples in the OTU table were rarefied to the same depth (considering the lowest number of sequences in a single sample) to remove the effect of sampling effort upon analysis. Alpha-diversity measurements (that is, OTU richness (unique OTUs), and ChaoI richness and Shannon diversity indices) were determined at cutoff values of $95 \%, 97 \%, 98 \%$ and $99 \%$ of nucleotide identity. A phylogenetic tree was inferred using muscle for sequence alignment, and FastTree (http://www.microbesonline.org/fasttree/). This generated a phylogenetic tree containing representative sequences of each OTU across all samples. Nonmetric multidimensional scaling plots were generated based on Bray-Curtis similarities calculated between different samples using the OTU table with OTUs clustered at 98\% nucleotide identity, using PRIMER software (Clarke and Gorley, 2006).

Nucleotide sequence accession numbers

The sequences reported in this study were deposited in GenBank under the accession numbers KF656791-KF657302. 


\section{Results}

This study evaluated the effects of realistic ocean water temperature increases on the photosynthetic quantum yield of the coral $M$. harttii in relation to the abundance and diversity of prokaryotic diazotrophs associated with this coral. The coral was exposed to water temperatures of $+1,+2$ and $+4.5^{\circ} \mathrm{C}$ above the ambient (baseline) temperature. Measurements were taken at three time points: (1) pretreatment (ambient); (2) after a 15-day acclimation period; and (3) 21 days after the onset of exposure. The maximum quantum yield of Photosystem II (Fv/Fm) after 21 days was not significantly different among replicates. However, differences between treatments were highly significant (analysis of variance $\mathrm{df}=3, \quad F=21543$, $P<0.000001$ ). The $\mathrm{Fv} / \mathrm{Fm}$ values declined at higher temperatures, and hence coral zooxanthella 'health' was negatively affected by higher temperature (Figure 1). Visual analysis of coral color and structure, according to the international Reef Check guidelines (and supported by pulse amplitude modulation fluorometry results), revealed that coral health indeed decreased significantly following exposure to a temperature increase of just $+2{ }^{\circ} \mathrm{C}$, and this effect increased at higher temperatures. In addition, the relative abundances of diazotrophs in the bacterial communities in the coral increased significantly $(P<0.05)$ in the +2 and $+4.5^{\circ} \mathrm{C}$ treatments when compared with those in the control (Figure 2). A peak in diazotroph abundance was observed in the $+2{ }^{\circ} \mathrm{C}$ treatment followed by the $+4.5^{\circ} \mathrm{C}$ treatment. Specifically, the +2 and $+4.5^{\circ} \mathrm{C}$ treatments showed about 7000 and 3500 nifH genes per $\mathrm{g}$ of coral, respectively, whereas the control showed 260 nifH genes per g of coral. This represented around 27- and 13-fold increases in the +2 and $+4.5^{\circ} \mathrm{C}$ treatments over the control, respectively. By contrast, 16S rRNA gene abundance showed increases of around five and twofold in the +2 and $+4.5^{\circ} \mathrm{C}$ treatments, respectively.

PCR-DGGE analysis of nifH genes confirmed that increased seawater temperature had an impact on the coral holobiont nifH gene complement. A clear tendency was found toward the formation of a single main nifH gene cluster in the samples with increased temperatures (Figure 3). This main cluster encompassed the nifH gene types found in most samples from the $+1,+2$ and $+4.5^{\circ} \mathrm{C}$ treatments, all of which clustered together within $\sim 72 \%$ similarity. The communities from three highertemperature samples $\left(+1{ }^{\circ} \mathrm{C} \mathrm{IV},+2{ }^{\circ} \mathrm{C} \mathrm{I}\right.$ and $+2{ }^{\circ} \mathrm{C}$ III) also clustered closely with this group, at $\sim 64 \%$ of similarity. The highest similarity values were found between the communities subjected to the largest temperature increase ( +2 and $+4.5^{\circ} \mathrm{C}$ ), with an overall similarity $>82 \%$. The pretreatment and control samples did not associate closely with any of the clusters recovered from the higher-temperature treatments. Within the increased-temperature $(+1$,

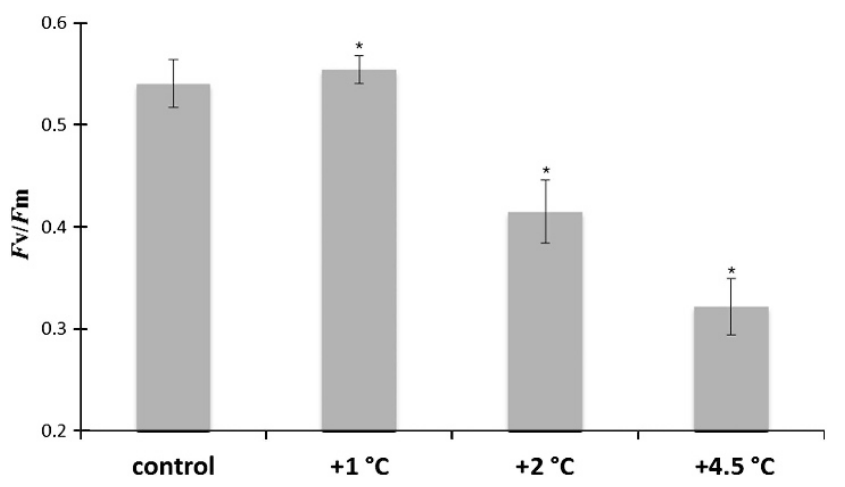

Figure 1 Dark-adapted Fv/Fm in Mussismilia harttii measured using a Diving-PAM chlorophyll fluorometer. *Three different elevated water temperatures $\left(+1.0,+2.0\right.$ and $\left.+4.5^{\circ} \mathrm{C}\right)$ above the ambient temperature.

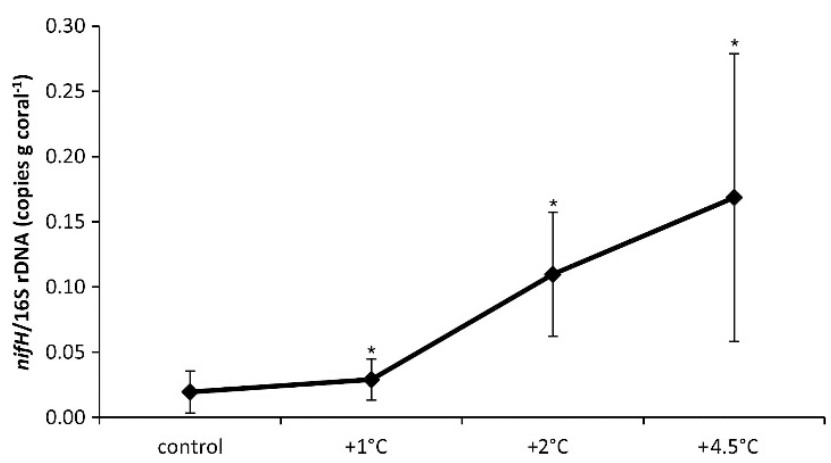

Figure 2 Relative abundance of nifH versus bacterial 16S rRNA gene (nifH/16S rRNA) copies per ng DNA determined by qPCR. $R^{2}$ (of standard curve) $>0.99$. The qPCR efficiency was about $99.0 \%$. Values: means from three replicates $(n=3) \pm$ standard error of the mean. ${ }^{*}$ Three different elevated water temperatures $\left(+1.0,+2.0\right.$ and $\left.+4.5^{\circ} \mathrm{C}\right)$ above the ambient temperature.

+2 and $+4.5^{\circ} \mathrm{C}$ ) treatments, the differences between the replicates were remarkably reduced when compared with the differences between replicates from both the pretreatment and control samples. Among the increased-temperature treatments, the nifH gene profiles from the $+1{ }^{\circ} \mathrm{C}$ treatment were most similar to those from the pretreatment and control samples.

Comparison of the diazotroph communities revealed that the pretreatment and control samples had similar OTU clusters, whereas those that had been subjected to the highest temperatures $(+2$ and $+4.5^{\circ} \mathrm{C}$ ) were most distant from these (Figure 4). The diversity and richness indices were significantly higher in the higher-temperature treatments $\left(+2\right.$ and $\left.+4.5^{\circ} \mathrm{C}\right)$ than in pretreatment and control samples (Table 1). Specifically, these diversity and richness indices were approximately threefold higher in the increased-temperature treatments at all cutoff values of nucleotide similarity that were used in the analyses.

Taxonomic analysis of the nifH sequences showed dominance of different diazotroph groups across the treatments. In both pretreatment and control 

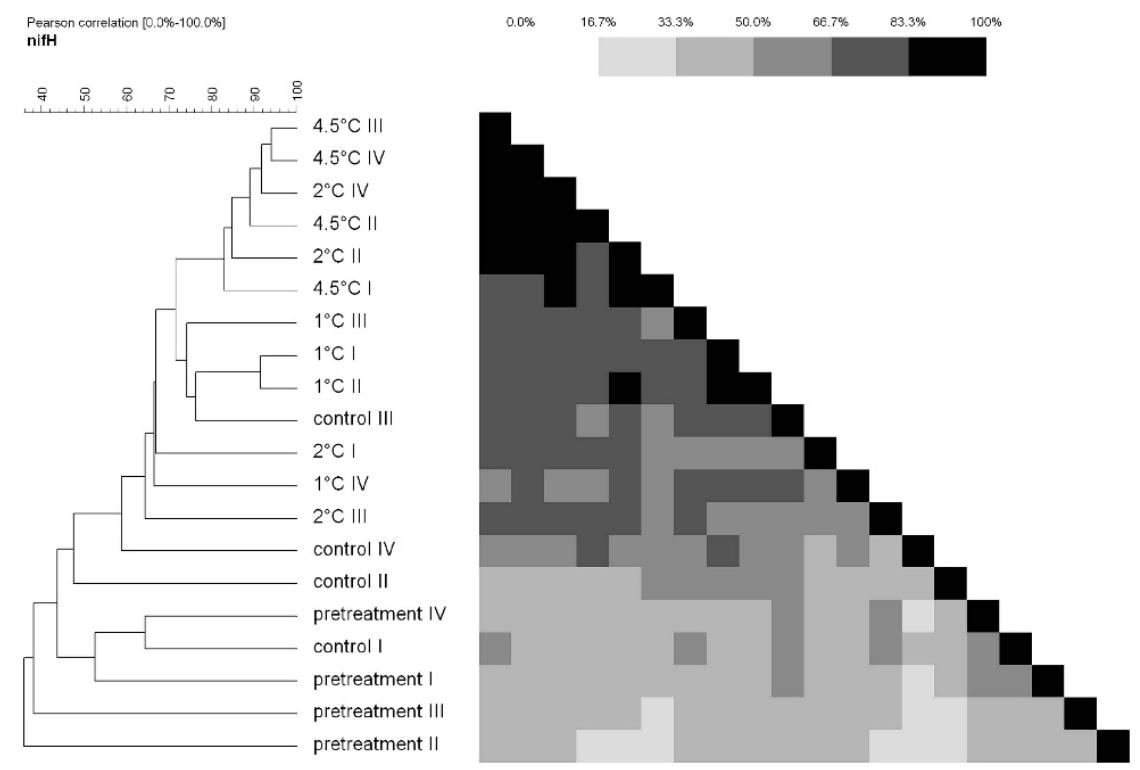

Figure 3 Dendrogram of PCR-DGGE profiles for the nifH gene created using UPGMA based on similarities calculated by densitometry.
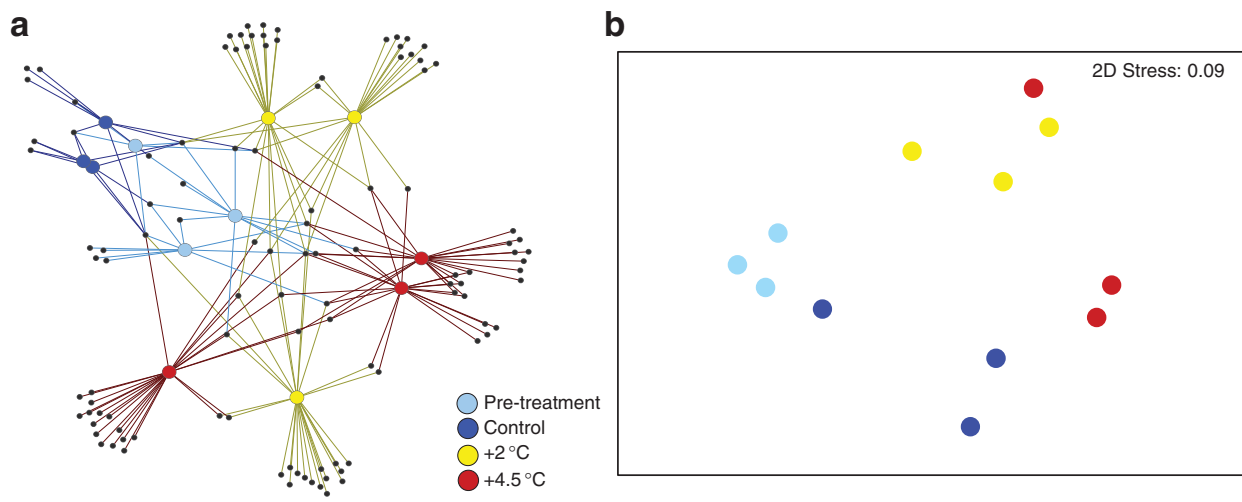

Figure 4 (a) Network of shared OTUs among treatment sequences, clustered at 98\% cutoff (nucleotide identity). (b) NMDS based on Bray-Curtis similarity matrix among the 12 samples from the mesocosms.

samples, nifH genes were mostly affiliated with class Gammaproteobacteria, with nifH genes from class Alphaproteobacteria representing the second most abundant group (Figure 5). By contrast, the phylum cyanobacteria was poorly represented in these communities ( 1 and 2 OTUs, respectively). However, the nifH genes recovered from samples taken from the higher-temperature treatments showed a considerable increase in the number of nifH sequence types. Specifically, the nifH genes from Alphaproteobacteria were more highly represented. At lower taxonomic levels, strong increases in Azospirillum-, Rhizobium- and Rhodobacter-like sequences were found. Strikingly, the relative abundance of Azospirillum-like sequences increased 8- and 21-fold in the +2 and $+4.5{ }^{\circ} \mathrm{C}$ treatments, respectively. Also, increases of 11- and 11.5-fold were found for typical Rhizobium-like sequences. Conversely, these shifts in dominant sequence types were reflected in decreases in the relative abundance of gammaproteobacterial nifH sequences. In addition, increases in the relative dominance of cyanobacterial nifH gene, in particular of the order Oscillatoriales, as well as those from Betaproteobacteria, were observed in the +2 and $+4.5^{\circ} \mathrm{C}$ treatments. Considering the betaproteobacterial nifH sequences, an uncontrolled tank effect, as these were not detected in pretreatment samples and appeared in both control (1 OTU) and treatment samples (2 OTUs) (Figure 5). Finally, only the $+4.5{ }^{\circ} \mathrm{C}$ treatment showed the presence of nifH genes typical for green sulfur bacteria (phylum Chlorobi).

\section{Discussion}

The observed shifts in the abundance and diversity of diazotrophs, seen in this study, should be considered in light of the known symbiotic 


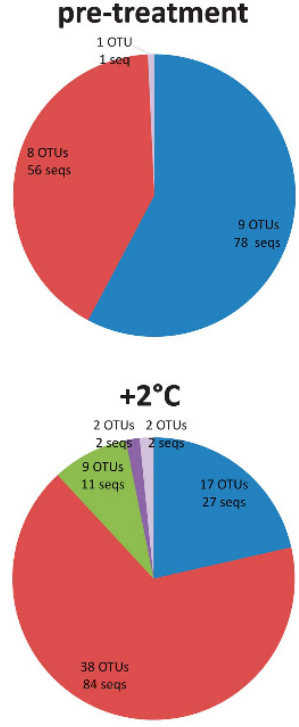

$\gamma$-Proteobacteria $\delta$-Proteobacteria
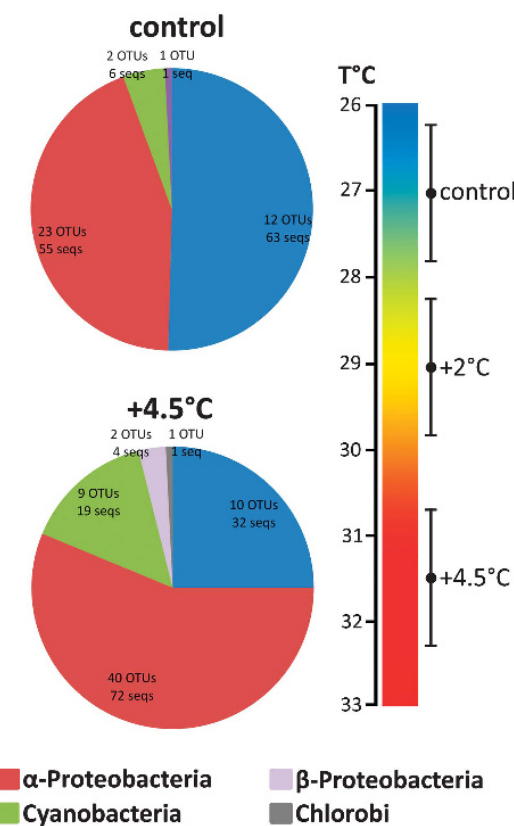

Figure 5 Taxonomic distribution of nifH-based OTUs among the different treatments. Sequences were clustered at a cutoff value of $98 \%$ of nucleotide similarity. Temperature averages in different treatments (control, +2 and $+4.5{ }^{\circ} \mathrm{C}$ ) during 21 days of experiment.

relationship between diazotrophs and zooxanthellae in corals. The growth of zooxanthellae in the coral system is probably limited by nitrogen availability (Falkowski et al., 1993; Lema et al., 2012). There is evidence that reduced nitrogen is often limiting in this ecosystem (O'Neil and Capone, 2008), and so the abundance and structure of diazotrophic communities become important. Indeed, coral photosynthesis rates under thermal stress have been shown to be higher in ammonium-supplemented corals than in untreated corals (Bérauda et al., 2013). On the other hand, increased levels of nitrogen have been found to cause stress in corals, including reduced reproduction and growth (Koop et al., 2001). The increase in the abundance of diazotrophs found in this study may be related to an increase in the numbers of zooxanthella, a response to the initial phases of thermal stress (Cunning and Baker, 2013), supporting initial survival of the holobiont organism when faced with temperature increases. Increased zooxanthella numbers may be a mechanism that explains $M$. harttii coral species resilience when confronted with thermal stress (Miranda et al., 2013). Nevertheless, at later stages of prolonged thermal stress, the zooxanthella density decreased (Cunning and Baker, 2013). The decrease of Fv/Fm in the +2 and $+4.5^{\circ} \mathrm{C}$ treatments detected in this study was indeed indicative of photo-induced damage of the PSII machinery that leads to coral zooxanthella density decreases (Takahashi et al., 2004). Concomitant with this decrease, the 
production of dimethylsulfoniopropionate often decreases (Van Alstyne et al., 2006), and, as such, the control of bacterial populations, some of which are potentially pathogenic, may be impaired (Slezakl et al., 1994; Raina et al., 2010; Barott and Rohwer, 2012). Hence, not only diazotrophs (such as measured here) but also other possibly deleterious bacterial groups may have thrived following the increase in temperature.

The increase in the abundance of Alphaproteobacterial nifH genes, in particular those related to Azospirillum, Rhodobacter and Rhizobium spp. (compared with Cyanobacteria), coupled with the decrease of gammaproteobacterial nifH genes suggests a scenario in which particular diazotrophs prevail when confronted with raised seawater temperatures. Azospirillum-like nifH genes were apparently favored in coral exposed to increased temperature. Measurement of $\mathrm{C}_{2} \mathrm{H}_{2}$ reduction activity in Azospirillum spp., $A$. brasiliense and A. lipoferum at 30 and $42{ }^{\circ} \mathrm{C}$ infers that these bacteria may be adapted to nitrogen fixation at elevated temperatures (Aggarwal and Chaudhary, 1995). This observation is consistent with the large increase in Azospirillum-like nifH sequences seen in the $+4.5{ }^{\circ} \mathrm{C}$ treatment compared with that in the $+2{ }^{\circ} \mathrm{C}$ treatment. Members of the genus Azospirillum have previously been found to be associated with another species of Mussismilia during bleaching stress and so they apparently thrive in stressed corals (De Castro et al., 2010).

Our finding of Rhodobacter-like nifH genes in the high-temperature treatments is consistent with the finding that these organisms may be associated with deleterious processes in coral as they are observed to be abundant in diseased corals at different localities (Mouchka et al., 2010). Furthermore, Rhizobiumlike diazotrophs, such as those detected in the present study, have already been documented in many other coral species (Lema et al., 2012). In terms of the Cyanobacteria-like sequences that were detected, both Trichodesmium and Lyngbya spp. have been reported to occur in blooms in coastal environments, including in corals, during the warmest seasons (O'Neil and Dennison, 2005; Paul et al., 2005; Ramos et al., 2005; Hewson et al., 2007; O'Neil and Capone, 2008; Paerl and Huisman, 2008). The results reported here highlight the importance of certain diazotroph groups in corals and their proliferation under high-temperature stress conditions. Moreover, we propose that the densities (abundance, as measured by direct qPCR) of particular diazotroph species could be used as coral reef health bioindicators. This would provide a relatively simple tool with which to monitor the impact of thermal stress on corals. In addition, modulation of diazotroph communities should be further evaluated for potential improvement of the fitness of corals during thermal stress - for example, through the use of bioaugmentation of heat-resistant diazotroph species.

\section{Conflict of Interest}

The authors declare no conflict of interest.

\section{Acknowledgements}

We thank Conselho Nacional de Desenvolvimento Científico e Tecnológico (CNPq), Petrobras Ambiental, Fundação de Amparo à Pesquisa do Estado do Rio de Janeiro (FAPERJ), Coordenação de Aperfeiçoamento de Pessoal de Nível Superior (CAPES), Coral Vivo Project and its sponsors (Petrobras and Arraial d'Ajuda Eco Parque) and Eduardo Fonseca for their support. The authors would also like to thank Professor Andrew Macrae (IMPPG/UFRJ) and Professor Ian Head (Newcaslte University, UK) for critical reading of the manuscript.

\section{References}

Aggarwal P, Chaudhary K. (1995). Biological nitrogen fixation at elevated temperature in different Azospirillum species and strains. Biol Fertil Soils 20: 260-262.

Bach HJ, Tomanova J, Schloter M, Munch JC. (2002). Enumeration of total bacteria and bacteria with genes for proteolytic activity in pure cultures and in environmental samples by quantitative PCR mediated amplification. J Microbiol Meth 49: 235-245.

Barott KL, Rohwer FL. (2012). Unseen players shape benthic competition on coral reefs. Trends Microbiol 20: 621-628.

Bérauda E, Gevaertb F, Rottiera C, Ferrier-Pagèsa C. (2013). The response of the scleractinian coral Turbinaria reniformis to thermal stress depends on the nitrogen status of the coral holobiont. J Exp Biol 216: 2665-2674.

Bourne DG, Iida Y, Uthicke S, Smith-Keune C. (2008). Changes in coral-associated microbial communities during a bleaching event. ISME J 2: 350-363.

Burke L, Reytar K, Spaulding M, Perry A. (2011). Reefs at Risk Revisited. World Resources Institute.

Caporaso JG, Kuczynski J, Stombaugh J, Bittinger K, Bushman FD, Costello EK et al. (2010). QIIME allows analysis of high-throughput community sequencing data. Nat Methods 7: 335-336.

Charlson RJ, Lovelock JE, Andreae MO, Warren SG. (1987). Oceanic phytoplankton, atmospheric sulfur, cloud albedo and climate. Nature 326: 655-661.

Chou HH, Holmes M. (2001). DNA sequence quality trimming and vector removal. Bioinformatics 17: 1093-1104.

Clarke KR, Gorley RN. (2006). PRIMER, 6th edn. PRIMER-E Ltd.: Plymouth, UK.

Cunning R, Baker AC. (2013). Excess symbionts increase the susceptibility of reef corals to bleaching. Nat Clim Change 3: 259-262.

De Castro AP, Araujo Jr SD, Reis AM, Moura RL, Francini-Filho RB, Pappas Jr G et al. (2010). Bacterial community associated with healthy and diseased reef coral Mussismilia hispida from eastern Brazil. Microb Ecol 59: 658-667.

Falkowski PG, Dubinsky Z, Muscatine L, McCloskey L. (1993). Population control in symbiotic corals. Bioscience 43: 606-611.

Falkowski PG, Dubinsky Z, Muscatine L, Porter JW. (1984). Light and the bioenergetics of a symbiotic coral. Bioscience 34: 705-709. 
Hewson I, Moisander PH, Morrison AE, Zehr JP. (2007). Diazotrophic bacterioplankton in a coral reef lagoon: phylogeny, diel nitrogenase expression and response to phosphate enrichment. ISME J 1: 78-91.

Hoegh-Guldberg O, Bruno JF. (2010). The impact of climate change on the world's marine ecosystems. Science 328: 1523-1528.

Hoegh-Guldberg O, Mumby PJ, Hooten AJ, Steneck RS, Greenfield P, Gomez E et al. (2007). Coral reefs under rapid climate change and ocean acidification. Science 318: 1737-1742.

Keller MD, Bellows WK, Guillard RRL. (1989). Dimethyl sulfide production in marine phytoplankton. In: Saltzman ES, Cooper WJ (eds), Biogenic Sulfur in the Environment. American Chemical Society: Washington, USA, pp 167-182.

Knowlton N, Rohwer F. (2003). Multispecies microbial mutualisms on coral reefs: the host as a habitat. Am Nat 162: 51-62.

Koop K, Broadbent AD, Booth D, Brodie J, Bucher D, Capone D et al. (2001). ENCORE: The effect of nutrient enrichment on coral reefs. Synthesis of results and conclusions. Mar Pollut Bull 42: 91-120.

Lema KA, Willis BL, Bourne DG. (2012). Corals form characteristic associations with symbiotic nitrogenfixing bacteria. Appl Environ Microb 78: 3136-3144.

Lesser MP, Falcon LI, Rodriguez-Roman A, Enriquez S, Hoegh-Guldberg O, Iglesias-Prieto R. (2007). Nitrogen fixation by symbiotic cyanobacteria provides a source of nitrogen for the scleractinian coral Montastraea cavernosa. Mar Ecol Prog Ser 346: 143-152.

Miranda RJ, Cruz ICS, Leão ZMAN. (2013). Coral bleaching in the Caramuanas reef (Todos os Santos Bay, Brazil) during the 2010 El Niño event. Latin Am Aquat Res 41: 351-360.

Mouchka ME, Hewson I, Harvell CD. (2010). Coral-associated bacterial assemblages: current knowledge and the potential for climate-driven impacts. Integr Comp Biol 50: 662-674.

O’Neil J, Dennison WC. (2005). Lyngbya majuscula in Southeast Queensland waterways. In: Abal EG, Dennison WC (eds), Healthy Waterways-Healthy Catchments. South East Queensland Regional Water Quality Strategy, Brisbane City Council. Moreton Bay Waterways and Catchments Partnerships: Brisbane, Queensland, Australia, pp 119-148.

O’Neil JM, Capone DG. (2008). Nitrogen cycling on coral reefs. In: Capone DG, Carpenter EJ, Bronk DA, Mulholland MR (eds), Nitrogen in the Marine Environment. Elsevier Press: The Netherlands, pp 949-989.

Olson ND, Ainsworth TD, Gates RD, Takabayashi M. (2009). Diazotrophic bacteria associated with Hawaiian Montipora corals: diversity and abundance in correlation with symbiotic dinoflagellates. J Exp Mar Biol Ecol 371: 140-146.

Paerl HW, Huisman J. (2008). Blooms like it hot. Science 320: $57-58$.

Paul VJ, Thacker RW, Banks K, Golubic S. (2005). Benthic cyanobacterial bloom impacts the reefs of South Florida (Broward County, USA). Coral Reefs 24: 693-697.

Pereira e Silva MC, Semenov AV, van Elsas JD, Salles JF. (2011). Seasonal variations in diversity and abundance of diazotrophic communities across soils. FEMS Microbiol Ecol 77: 57-68.
Poly F, Monrozier LJ, Bally R. (2001). Improvement in the RFLP procedure for studying the diversity of nifH genes in communities of nitrogen fixers in soil. Res Microbiol 152: 95-103.

Raina J, Dinsdale E, Willis B, Bourne D. (2010). Do the organic sulfur compounds DMSP and DMS drive coral microbial associations? Trends Microbiol 18: 101-108.

Ramos AG, Martel A, Codd GA, Soler E, Coca J, Redondo A et al. (2005). Bloom of the marine diazotrophic cyanobacterium Trichodesmium erythraeum in the Northwest African upwelling. Mar Ecol Prog Ser 301: 303-305.

Reshef L, Koren O, Loya Y, Zilber-Rosenberg I, Rosenberg E. (2006). The coral probiotic hypothesis. Environ Microbiol 8: 2068-2073.

Rohwer F, Seguritan V, Azam F, Knowlton N. (2002). Diversity and distribution of coral-associated bacteria. Mar Ecol Prog Ser 243: 1-10.

Rosenberg E, Koren O, Reshef L, Efrony R, Zilber-Rosenberg I. (2007). The role of microorganisms in coral health, disease and evolution. Nat Rev Microbiol 5: 355-362.

Santos HF, Carmo FL, Leite DCA, Jesus HE, Maalouf PC, Almeida C et al. (2012). Comparison of different protocols for the extraction of microbial DNA from reef corals. Braz J Microb 43: 517-527.

Schreiber U. (2004). Pulse-amplitude-modulation (PAM) fluorometry and saturation pulse method: an overview. In: Papageorgiou GC, Govindjee (eds), Advances in Photosynthesis and Respiration. Springer The Netherlands, pp 279-319.

Selig ER, Harvell CD, Bruno JF, Willis BL, Page CA, Casey KS et al. (2006). Analyzing the relationship between ocean temperature anomalies and coral disease outbreaks at broad spatial scales. In: Phinney JT et al. (eds), Coral Reefs and Climate Change: Science and Management. American Geophysical Union: Washington, USA, pp 111-128.

Simonet P, Grosjean MC, Misra AK, Nazaret S, Cournoyer B, Normand P. (1991). Frankia genusspecific characterization by polymerase chain reaction. Appl Environ Microbiol 57: 3278-3286.

Slezakl DM, Puskaric S, Herndll GJ. (1994). Potential role of acrylic acid in bacterioplankton communities in the sea. Mar Ecol Prog Ser 105: 191-197.

Sutherland KP, Porter JW, Torres C. (2004). Disease and immunity in Caribbean and Indo-Pacific zooxanthellate corals. Mar Ecol Prog Ser 266: 273-302.

Takahashi S, Nakamura T, Sakamizu M, van Woesik R, Yamasaki H. (2004). Repair machinery of symbiotic photosynthesis as the primary target of heat stress for reef-building corals. Plant Cell Physiol 45: 251-255.

Taketani RG, Santos HF, van Elsas JD, Rosado AS. (2009). Characterization of the effect of a simulated hydrocarbon spill on diazotrophs in mangrove sediment mesocosm. Antonie van Leeuwenhoek 96: 343-354.

Tamura K, Dudley J, Nei M, Kumar S. (2007). MEGA4: Molecular Evolutionary Genetics Analysis (MEGA) software version 4.0. Mol Biol Evol 24: 1596-1599.

Van Alstyne KL, Schupp P, Slattery M. (2006). The distribution of dimethylsulfoniopropionate in tropical Pacific coral reef invertebrates. Coral Reefs 25: 321-327.

Wild C, Woyt H, Huettel M. (2005). Influence of coral mucus on nutrient fluxes in carbonate sands. Mar Ecol Prog Ser 287: 87-98. 